\title{
The Impact of Personal Selling on the Purchasing Behavior towards Clothes: A Case Study on the Youth Category
}

\author{
Rudain Othman Yousif ${ }^{1}$ \\ ${ }^{1}$ Department of Marketing, Faculty of Economic and Administrative Science, Al-Zarqa University of Jordan, \\ Zarqa, Jordan \\ Correspondence: Rudain Othman Yousif, Department of Marketing, Faculty of Economic and Administrative \\ Science, Al-Zarqa University of Jordan, Zarqa, Jordan. Tel: 962-6-586-2982. E-mail: \\ dr.rudaina_othman@yahoo.com
}

Received: July 15, 2016 Accepted: August 30, $2016 \quad$ Online Published: September 22, 2016

doi:10.5539/ijms.v8n5p128 URL: http://dx.doi.org/10.5539/ijms.v8n5p128

This article has been supported by the Deanship of Scientific Research in Al-Zarqaa University, Jordan.

\begin{abstract}
This study aimed to find the impact of personal selling on the purchasing behavior for youth in buying clothes. To achieve the objectives of the study, hypotheses were formulated and tested on a sample of the target community made up of 289 young men and women. The questionnaire design (32) was divided into five dimensions, four dimensions based on the personal characteristics of salespersons and their display of goods, characteristics of clothing stores, promotion done by salespersons in the sale of clothing, and the fifth focused on youth's clothes purchasing behavior. The results of the study showed that $76.7 \%$ of males and $99.1 \%$ of females prefer to purchase from clothing retail stores. The sampling showed that salespersons in retail stores are honest in dealing with their customers but do not have the ability to negotiate with them. They neither have the required sales skill nor play a big role in stimulating sales, and they do not grant discounts to customers. The study recommended the importance of training and qualification for salespersons in personal selling to help them deal truthfully with customers and develop the ability to negotiate. Salespersons should be granted the authority to give discounts to customers.
\end{abstract}

Keywords: personal selling, buying behavior, salespersons, purchasing behavior, clothes

\section{Introduction}

The successful organizations in business are those that are able to achieve success in the study of consumer behavior and determine the factors that affect the development of marketing strategies, which enable them to reach the target consumers through the process of personal selling. The process of direct contact between buyer and seller plays an active role in strengthening the relationship between both of them. This is reflected, in turn, in the decision to purchase products displayed in retail stores; therefore, organizations are giving a great consideration to hiring salespersons because they are aware that they represent a key element in the achievement of personal selling in contact with buyers and in creating a good impression about the organization and its products. Personal selling is defined as a face-to-face contact process between buyer and seller in order to achieve planned goals, which are sales, and build long-standing relations with consumers (Kotler \& Armstrong, 2013). Personal sales success depends on the implementation of eight processes: searching for salespersons, determining the course of action, assessing needs, nature of the offer, method of presentation, dealing with objections, commitment, and follow-up (Spiro et al., 2008).

Personal selling represents the strategy that salespeople use to persuade customers to buy their products, provide them with all the information relating to the products, and work to eliminate consumer fears about such goods (Laura, 2016). Ahlam (2006) indicates that workers in personal selling work to convince consumers to make a purchase decision and that the personal characteristics, which are characterized by a man showing great personal strength and confidence and the ability to persuade and negotiate, are instrumental to winning consumers, influencing buying, guiding decision about replacement of items and even trying to help them get unavailable commodities they are seeking to buy. 


\section{Research Problems}

The organization's efforts in the study of the marketing environment and collection of information are based on drawing the strategic elements of the marketing mixture - product, pricing, promotion, and distribution. It will not succeed unless these organizations succeed in reaching consumers through the provision of products in good time and place and in choosing the sales force capable of dealing with consumers and responding to their needs and desires in the light of the increasing number of shops, diversity of products, dramatically increasing demand, and the increasing volume of displayed commodities. All these contribute to the complexity in the work of employees in personal sales and exert a lot of pressure on them. Workers in the personal sales sector in developing countries are not selected or appointed based on a systematic process or deliberate manner that could enable the organization to achieve its goals. From the foregoing, the research questions were formulated as follows.

1). What is the impact of the personal characteristics of salespersons on the purchasing behavior towards clothes?

2). Does the presentation of the goods by salespersons affect the purchasing behavior towards clothes?

3). Do the characteristics of clothing and location affect the purchasing behavior towards clothes?

4). Does sales promotion by salespersons have any effect on the purchasing behavior towards clothes?

\section{Research Objectives}

The main objective of this research was to identify the impact of personal selling and purchasing behavior of young consumers towards clothes. Personal selling and organizations' staff represent the link between the organization and consumers. Deficient personal selling will reflect negatively on the performance of the organization and its ability to achieve set goals. Given the above, this study aims to:

1). Identify the impact of the characteristics of the salespersons on the purchasing behavior of young consumers.

2). Identify the impact of the presentation of the goods by salespersons on the purchasing behavior of young consumers.

3). Identify the impact of the characteristics of clothing stores and their location on the purchasing behavior of consumers.

4). Identify the impact of sales promotion by salespersons on the purchasing behavior of young consumers.

\section{Research Hypotheses}

Based on the study questions and objectives, the hypotheses of the study are:

H0: No statistically significant effect at the level $(a \leq 0.05)$ of sale on the personal decision of young consumers purchasing clothing.

H01: No effect is statistically significant at the level of significance $(a \leq 0.05)$ on the personal characteristics of the salespersons on the purchasing behavior of young consumers towards clothes.

H02: No effect is statistically significant at the level of significance $(a \leq 0.05)$ to view the goods by salespersons on the purchasing behavior of young consumers towards clothes.

H03: No effect is statistically significant at the level of significance $(a \leq 0.05)$ in terms of the characteristics of clothing stores and its location on the purchasing behavior of young consumers.

H04: No effect is statistically significant at the level of significance $(a \leq 0.05)$ for the promotion done by salespersons on the purchasing behavior of young consumers towards clothes.

\section{Study Model}

The following diagram shows the study model. 


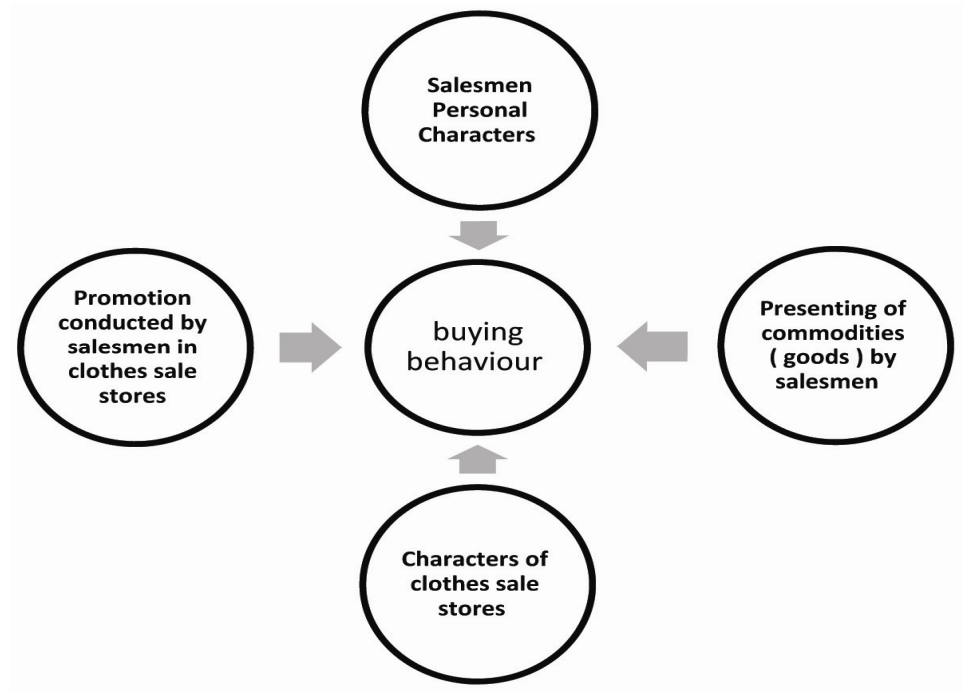

Figure 1. Study model

\section{Literature Review}

Referring to the study done to develop marketing \& sales skills (Arabic Forum, 2016), the importance of personal sale arises as salespersons act like a connection ring between the organization and consumers. Personal salespersons contribute to creating an excellent mental impression and a good image for the organization among its customers.

Besides the major role that personal selling plays in the promotion program to implement marketing plans for the organization, using personal sale by women groups largely affects the increase of product sales - by walking from door to door, walking in markets, telling people about their products and persuading them to buy. Peoples' knowledge of the product is raised further, and the product awareness will increase sales. After peoples' awareness they expect an increase in sales. (Murianki, 2015)

By studying the impact of promotion mixture elements on decisions of Jordanian consumers in using cellular phones (Mobiles) (Hani \& Mohammad, 2008), it was found that activating sales factor is the most effective factor of consumer decision in choosing a communication firm as well as usage, compared with other factors. The importance of commercial advertising and personal sales is weakened when we take each one alone. The study is concerned with identifying customer satisfaction about salespersons concerning presentation, capability to negotiate, knowledge issues, skills, providing services and external appearance. The study concluded that the customers are satisfied with salespersons' performance, which stresses the importance of the role played by personal sales to achieve customer satisfaction. (Mohammad, 2007)

In addition, personal sale is a very effective factor in establishing contact between salespersons and buyers in two directions. The customers can inquire and ask the salespersons face-to-face questions. At the same time, they can discuss and reach a clear understanding and take a proper buying decision, which encourages them to re-deal. (Alsamydai \& Yousif, 2010) To identify and know more about the impact of personal sale on increasing sales volume from retail merchants to prospective consumers, we take as a case study Alejawi Company, where a comparison is made between what was spent on personal sale and sales each year. After the analysis is done, a strong relation with strong impact between accomplished sales quantity and personal sale for each year was found. This demonstrates that personal sale has an important role in increasing sales. But the study indicated that there is no impact from the gender factor, scientific qualification and years of experience of salespersons on increasing sales quantity from the point of view of the retail merchants. (Samer et al., 2012)

Ziad (2010) reveals that salespersons' credibility, commitment to the promises, patience in dealing with customers and their appearance have a great impact on customer satisfaction. Retail merchants in direct sale stores have a fundamental role in gaining customers, providing them with relevant information that affects their buying decision. (Azam et al., 2016)

The employers in personal sale are able to affect the clothes-buying behavior of customers when they are aware of all information concerning the commodities they are selling and their competitors. In addition, when they listen to customers, dialogue with them and identify their needs, all these will make them complete the selling 
process (Gayath, 2001). The interaction between salespersons and customers and the quick response from them play a great role in identifying the demands and desires of the customers and fulfilling them (Ashleyet, 2011).

\section{Research Methodology and Information Collection}

The study targeted the identification of the impact of personal selling on the youth's clothes buying decision. To achieve this, the researcher depended on secondary resources represented by the available literature. In addition, the researcher depended on designing a questionnaire composed of 32 questions that were implemented on a sample of 289 youth. The sample members (individuals) preferred to deal with specialized clothing stores and dealt directly with salespersons as explained in Table 1.

Table 1. Preference of buying clothes from clothing stores

\begin{tabular}{llllll}
\hline Gender & Yes & & NO & & Total \\
\hline Male & 132 & 0.767 & 40 & 0.233 & 172 \\
Female & 116 & 0.991 & 1 & 0.009 & 117 \\
\hline Total & 248 & 0.858 & 41 & 0.142 & 289 \\
\hline
\end{tabular}

Females are more willing to deal with specialized clothing stores $(0.991 \%)$ compared to males; $0.767 \%$ of them prefer to deal with specialized clothing stores; $0.233 \%$ prefer buying from division stores and "help yourself" stores.

\subsection{Test of Reliability}

Cronbach's alpha test was used to determine the fitness of the measuring tool and it was concluded that a $=.69 .2 \%$, which is an excellent value when the accepted percentage is higher than $60 \%$. Furthermore, the validity of the measuring tool was tested by consulting a panel of expert judges whose opinions were taken into consideration while designing the questionnaire in its current final version.

\subsection{Results Analysis}

1) Results concerning the first question (What is the impact of salespersons' personal characters on consumer buying behavior towards clothes) answer the question. The average was concluded for salespersons' personal characteristics and the total average for all these characters, also the value of ( $\mathrm{t}$ ) was found (one simple test). By using the two scales, it was found that each trait, e.g., honesty of salespersons and their capability for the required skill, was evaluated less than the measurement average (3), and the value of (t) test is less than the tabular value (1.96), and the value of Sig is greater than (0.05). This indicated that sampled individuals felt that salespersons are not honest, are incapable of negotiating with customers, and do not have enough skills. But, generally speaking, all characters' results show that the average answer to the first question is 3.4056, and the value of calculated test is 14.134 , and it is greater than the tabular value (1.96), and the value of Sig is 0.00 , which is less than 0.05 . These results show that customer evaluation for personal character is generally good.

Table 2. Salespersons personal characters

\begin{tabular}{llll}
\hline Questions & Mean & T & Sig. (2-tailed) \\
\hline 1. Do you find salespersons in clothes sale stores honest in dealing with buyers? & 2.6443 & -4.613 & .000 \\
2. Do salespersons in clothes sale stores have sufficient information about the commodities (goods) & 3.8289 & 14.835 & .000 \\
they are dealing with? & & & \\
3. Salespersons in clothes sale stores have good negotiation capability. & 2.9631 & -.563 & .574 \\
4. Salespersons in clothes sale stores have good capability to persuade. & 4.0403 & 16.698 & .000 \\
5. Salespersons in clothes sale stores are described to have an attractive appearance. & 4.2248 & 22.601 & .000 \\
6. Salespersons in clothes sale stores are described to have a balanced personality. & 3.3859 & 5.457 & .000 \\
7. Salespersons in clothes sale stores own the required skills. & 2.9094 & -1.913 & .057 \\
8. Salespersons in clothes sale stores have the capability of helping you to make proper choices of & 3.2483 & 2.817 & .005 \\
clothes that are suitable you. & & & \\
\hline Salespersons Personal Characters (H1) & 3.4056 & 14.134 & .000 \\
\hline
\end{tabular}

2) Presentation of commodities (goods) by salespersons.

Here we present the results concerning the second question [Does the way of presenting commodities (goods) by salespersons impact consumers' buying behavior towards clothes?]. To answer that question, the average and the 
grand average were derived and the value of $(\mathrm{t})$, one simple test, was derived. As mentioned in table 3 , from the two scales, it appears that the average of all sections exceeds the average value of unit scale (3).

Results show that the general average is 3.5190 and the value of calculated test is 14.557 and it is greater than the tabular value (1.96) and the value of Sig is 0.00 which is less than 0.05 .

From these results, it is clear that customer evaluation for presenting commodities (goods) by salespersons is good and accepted.

Table 3. Presenting of commodities (goods) by salespersons

\begin{tabular}{llll}
\hline Questions & Mean & t & Sig. (2-tailed) \\
\hline 9. Salespersons present to you the proper clothes that fit you. & 3.9094 & 16.957 & .000 \\
10. Salespersons present to you the clothes that motivate you to buy. & 3.1644 & 2.9094 & .036 \\
11. Salespersons listen carefully to you so that he can present the material suitable for you. & 3.7919 & 13.027 & .000 \\
12 Salespersons present to you more than one commodity to enable you to select what is & 3.5302 & 8.154 & .000 \\
suitable. & 3.3893 & 5.672 & .000 \\
13. Salespersons are patient while dealing with buyers and presenting commodities to them. & 3.3289 & 5.595 & .000 \\
14. Salespersons are flexible enough when presenting the commodity. & 3.5190 & 14.557 & .000 \\
\hline Presenting of commodities (goods) by salespersons (H2) & & &
\end{tabular}

3) Now to results concerning the third question (Do the characters of clothes sale stores and their location have an impact on consumers' buying behavior towards clothes?). We answer that question from the results of statistical analysis in table 4, which shows that the average of all sections exceeds the average value of the scale unit (3), and the total average is (3.6907). The calculated test value is 29.449 ; it is greater than the tabular value (1.96) and the value of Sig is 0.00 , which is less than 0.05 . These results show that evaluation of the customers for the characters of clothes sale stores and their location is good.

Table 4. Characters of clothes sale stores

\begin{tabular}{llll}
\hline Questions & Mean & $\mathrm{t}$ & Sig. (2-tailed) \\
\hline 15. Clothes sale stores are described to be large enough that you may take your shopping tour & 3.6913 & 11.540 & .000 \\
and move easily. & 3.2584 & 4.505 & .000 \\
16. Clothes sale stores are described with their special internal order. & 3.2483 & 3.186 & .000 \\
17. The clothes are displayed in an attractive way on the store fronts. & 3.6711 & 8.033 & .000 \\
18. Decorations of retail stores are described to be of high-class taste. & 4.1611 & 21.748 & .000 \\
19. The internal order in clothes sale stores helps you to get the required commodity easily. & 4.1141 & 21.755 & .000 \\
20. The location of clothes sale stores makes it easy for the buyer to reach them. & 3.6907 & 29.449 & .000 \\
\hline Characters of clothes sale stores (H3) & & & \\
\hline
\end{tabular}

4) Now for results concerning the fourth question (Do promotion conducted by salespersons have an impact on consumers' buying behavior towards clothes?). We answer that question from the results of the statistical analysis in table 5, which shows that the average of question 21 and 22 did not exceed the average value of the scale unit (3). This indicates that customers found that salespersons do not play a great role in promoting commodities and do not provide discounts that encourage customers to repeat the buying process.

Table 5. Promotion conducted by salespersons in clothes sale stores

\begin{tabular}{llll}
\hline Questions & Mean & t & Sig. (2-tailed) \\
\hline 21. Salespersons play an important role to promote commodities in retail stores. & 2.8456 & -1.993 & .047 \\
22. Salespersons provide discounts in retail clothes sale stores which encourage you to deal & 2.9832 & -.177 & .859 \\
with them repeatedly. & & & \\
23. Salespersons play a major role in retail clothes sale stores to build reputation / fame for & 3.6477 & 10.155 & .000 \\
the store and commodities he deals with. & 3.2550 & 3.829 & .000 \\
24. Salespersons play a major role in retail clothes sale stores to stir up and inflame demand. \\
$\begin{array}{l}\text { 25. Salespersons play a major role in retail clothes sale stores to attract buyer attentions. } \\
\text { 26. Salespersons play a major role in retail clothes sale stores to build up a positive image } \\
\text { about commodities. }\end{array}$ & 3.6879 & 10.108 & .000 \\
27. Salespersons identify commodities by an attractive way. & 4.2718 & 25.805 & .000 \\
\hline Promotion conducted by salespersons in clothes sale stores (H4) & 3.5105 & 14.204 & .000 \\
\hline
\end{tabular}




\section{5) Buying behavior}

The results of statistical analysis in table 6 show that the buying behavior towards clothes is affected by salespersons' personal characters, their way of presentation (demonstration), the internal order of the store, its location, the direct contact with the salesperson and what they provide as promotion activities.

Table 6. Buying behavior

\begin{tabular}{|c|c|c|c|}
\hline Questions & Mean & $\mathrm{t}$ & Sig. (2-tailed) \\
\hline $\begin{array}{l}\text { 28. Personal characters of salespersons play an important role in influencing buying behavior } \\
\text { towards clothes. }\end{array}$ & 4.0839 & 25.111 & .000 \\
\hline 29. Salespersons way of presenting has an impact on buying behavior of clothes. & 3.8893 & 12.317 & .000 \\
\hline 30. The internal order in clothes sale stores has an impact on buying behavior towards clothes. & 3.9597 & 15.923 & .000 \\
\hline $\begin{array}{l}\text { 31. Salespersons promote commodities (clothes) they are dealing with, which has an impact on } \\
\text { buying behavior towards clothes. }\end{array}$ & 3.5738 & 9.357 & .000 \\
\hline $\begin{array}{l}\text { 32. Face to face contact between salesperson and buyer has an impact on buying behavior } \\
\text { towards clothes. }\end{array}$ & 3.6946 & 11.424 & .000 \\
\hline Purchasing behavior (H5) & 3.8403 & 22.958 & .000 \\
\hline
\end{tabular}

\section{6) Analysis of multiple regressions}

The validity of the form of linear multiple regression is clear from the results identified in Table 7 . What supports this is the calculated value (F) (99.322), which is greater than the table value (2.35), and the value of Sig. is 0.00 which is less than 0.05 . Based on this, we reject the null hypothesis and accept the alternative one, which indicates that there is an impact of personal sales on youth buying behavior towards clothes, personal sales factors found in salespersons' personal characters, the way clothes are presented by salespersons, characters of clothes sale stores and promotion done by salespersons. The determining factor presents 0.576 , which indicates that personal selling factors explain about $57.6 \%$ of the changes that affect youth buying behavior towards clothes.

Table 7. Multiple regression

\begin{tabular}{lllll}
\hline R (correlation) & R Square & F & Sig. & df \\
\hline 0.759 & 0.576 & 99.322 & 0.000 & $4 / 293 / 297$ \\
\hline
\end{tabular}

From the results of Table 7, we can use linear multiple regressions to measure the impact of personal sale on youth buying behavior towards clothes as in Table 8 .

Table 8. Personal selling elements

\begin{tabular}{llllll}
\hline & $\mathrm{t}$ & Beta & Std. Error & $\mathrm{B}$ & Sig. \\
\hline Constant & 9.673 & & .283 & 2.735 & .000 \\
Salespersons personal characters & & & & & \\
Presenting of commodities (goods) by salespersons & -4.811 & -.214 & .057 & -.272 & .000 \\
Characters of clothes sale stores & 3.327 & .139 & .043 & .143 & .000 \\
Promotion conducted by salespersons in clothes sale stores & -5.813 & -.241 & .065 & -.376 & .001 \\
Salespersons' personal characters & 18.965 & .816 & .044 & .831 & .000 \\
\hline
\end{tabular}

\section{Dependent Variable: H5}

The table value of $t$ is 293 and the indicator (0.05) and Tabular Value (1.96) show that the personal characters of salespersons and characters of clothes sale stores were not available due to the opinions of sampled individuals because the value of test $(t)$ is negative.

On the other hand, the way salespersons present clothes and promote sales was found to be very effective in retail stores as the sampled individuals explain.

\section{Discussion}

The sampled individuals prefer to deal with specialized stores in clothes sale. Females' preference was $99.1 \%$ and male $76.7 \%$. The sampled individuals found that salespersons in clothes sale stores were not honest in 
dealing with customers (2.6443) and did not have the capability to negotiate (2.9631); they also did not have the required skill (2.9094). The salespersons did not present clothes to customers in a way that encouraged them to buy (2.9094). The salespersons played a small role in activating sales to affect buying behavior (2.8456).

Hani \& Mohammad (2008) showed a role in activating sales factor. The salespersons did not provide discounts to customers to encourage them to buy (2.9832). This is not compatible with the study results.

Personal sale has an impact on youth buying behavior towards clothes because the value calculated $(\mathrm{F})$ equals 99.322, which is greater than the tabular value (2.35) and the value of Sig $(0.00)$ which is less than 0.05. Based on that, we reject the null hypothesis and accept the alternative one that demonstrates the impact of personal sale on youth buying behavior towards clothes. There are other factors of personal sale, like personal characters of salespersons, presentation of commodities by salespersons, characters of clothes sale stores and promotion conducted by salespersons. The identification factor presents 0.576 , which indicates that personal sale factors explain what is $57.6 \%$ for changes to occur on youth buying behavior towards clothes.

The analysis of multiple regressions in Table (8) shows that salespersons in personal sale did not have the required characters. The value test $(\mathrm{t})$ is -4.811 , which is less than the tabular value (1.96); it is the same for characters of clothes sale stores.

This study showed that sampled individuals found that salespersons were not honest in dealing with customers, which contradicts Ziad (2010) who showed that the honesty of salespersons, their commitments to their promises and their patience in dealing with customers had an impact on their behavior.

\section{Recommendations}

Arising from the research results, the researcher provides the following recommendations:

1) to work on salespersons' awareness about the importance of dealing honestly with customers because dishonesty will remove the confidence from them and drive customers to find another sales point for buying clothes. These impact negatively on sales volume;

2) to work on the training and qualification of salespersons and increase their capabilities to negotiate so that they can deal properly with customers;

3) to equip salespersons with the required flexibility, which enables them to activate sales and provide discounts to customers with the aim of encouraging them to buy;

4) to work on developing the personal characters of salespersons and paying more attention to stores concerning internal order and choosing the proper location to simplify customers' ability to reach the sales point.

\section{References}

Ahmed, A. Z., Hassouna, A. B., \& Saeed, S. M. (2016). The principles of the modern theory and practice of marketing. Ammaan, Jordan: Dar Massira for publication and distribution. http://dx.doi.org/10.2753/PSS0885-3134280401

Alakaylh, Z. A. H. (2010). The extent of understanding the ethical behavior of salespeople and its role in achieving customer satisfaction in the market (business to business). (A field study of the auto parts market in Amman city). Masters thesis. Middle East University. Retrieved from http://elibrary.mediu.edu.my/books/2014/MEDIU5953.pdf

Anyadighibe, J. A., Awara, N. F., \& Esu, B. B. (2014). The impact of personal selling on the productivity of selected banks in Calabar metropolis. International Journal of Development and Sustainability, 3(8), 1697-1708.

Ashley, C., Noble, S. M., Donthu, N., \& Lemon, K. N. (2011). Why customers won't relate: Obstacles to relationship marketing engagement. Journal of Business Research, 64, 749-756. http://dx.doi.org/10.1016/j.jbusres.2010.07.006.

Dystrophy, H. M. H., \& Shuraidah, T. (2008). The impact of promotional mix elements of the Jordanian consumer in the use of cellular phone service decisions: Analytical study. Jordan Journal of Business Management, 4(4), 375. Retrieved from http/journals.ju.edu.jo/JJBA/article/viewFile/692/690

Ghazi, A. A. (2006). Factors influencing the success of sales and marketing profile. Thesis for masters degree in Business / Marketing Department, Jordan University. Retrieved from http://iefpedia.com/arab/wp-content/uploads/2010/04/bbb.pdf

Jerpi, L. (2016). Marketing Strategies for Personal Selling. Retrieved from 
$\mathrm{http}: / /$ smallbusiness.chron.com/marketing-strategies-personal-selling-46563.html

Kotler, P. T., \& Armstrong, G. (2013). Principles of marketing (15th ed.). New Jersey: Pearson Prentice Hall.

Mahmod, J. A., \& Rudaina, O. Y. (2010). Sales Management. Ammaan, Jordan: Dar Massira for publication and distribution.

Murithi, M. M. (2015). Effects of personal selling on sales: A case of women groups in Imenti North District, Meru County, Kenya. International Journal of Academic Research in Business and Social Sciences, 5(1). http://dx.doi.org/10.6007/IJARBSS/v5-i1/1398.

Rapp, A., Agnihotri, R., \& Forbes, L. P. (2008). The sales force technology-performance chain: The role of adaptive selling and effort. Journal of Personal Selling \& Sales Management, XXVIII(4). http://dx.doi.org/10.2753/PSS0885-3134280401

Razzaq, M. J. A. (2007). Assess the level of customer satisfaction with the performance of salesmen national pharmaceutical companies in the Gaza market. Faculty of Trade, Business Administration Department, Commerce College.

Roseann, L. S., Gregory, R., \& Stanton, W. (2008). Management of a Sales Force (12th ed.). Boston, MA: Irwin/McGraw-Hill.

Sawalha, S., Ashraf, P., \& Mohamed, J. (2012). The impact of personal selling to increase sales volume from the viewpoint of retailers as a case study in the company Ajaoa. Marketing Department, Faculty of Economics. Retrieved from https://www.nmisr.com/vb/showthread.php?t=232901

The first Arab Forum for the development of marketing and sales skills. (2016). The concept of personal selling. Retrieved from http://www.tas-wiki.com/tw7428.html

Turgeman, G. (2001). The reality of personal selling and sales management in media companies in Syria and Damascus University. Damascus University, Faculty of Economics. Retrieved from http://www.damascusuniversity.edu.sy/mag/law/old/economics/2001/17-2/giath.pdf

\section{Copyrights}

Copyright for this article is retained by the author, with first publication rights granted to the journal.

This is an open-access article distributed under the terms and conditions of the Creative Commons Attribution license (http://creativecommons.org/licenses/by/4.0/). 